\title{
Teaching the History of U.S. Higher Education: A Critical Duoethnography
}

\author{
Z Nicolazzo \\ Northern Illinois University, \\ Dekalb, Illinois, USA
}

\author{
Susan B. Marine \\ Merrimack College, North \\ Andover, Massachusetts, USA
}

Marines@merrimack.edu

\begin{abstract}
In this duoethnography, we interrogate our roles as critical pedagogues in designing and teaching a graduate level course focused on the history of U.S. higher education. Throughout this dialogue, we surface tensions around what it means to enact critical pedagogy. Rather than just espousing a critical stance, we wrestle with how external pressures such as limited time, the need and desire to convey certain information to students, and neoliberalism influence the doing of critical pedagogy. We also discuss how our social identities, as well as those of the students alongside whom we teach and learn, affect the learning process. We conclude our paper by drawing upon our experiences and dialogue to consider what it means to do - rather than just espouse - a critical pedagogical style in the study of higher education.
\end{abstract}

Keywords: Critical pedagogy, history of higher education, graduate education.

\section{Introduction}

Teaching to transform is a complex, multi-layered, and evolving enterprise, marked by the intention to bring new forms of consciousness to students, so that they may be put to use in the service of social change. To this effect, Stephen D. Brookfield (1995) stated:

We teach to change the world. The hope that undergirds our efforts to help students learn is that doing this will help them act toward each other, and toward their environment, with compassion, understanding, and fairness. But our attempts to increase the amount of love and justice in the world are never simple, never unambiguous. What we think are democratic, respectful ways of treating people can be experienced by them as oppressive and constraining. One of the hardest things teachers have to learn is that the sincerity of their intentions does not guarantee the purity of their practice. The cultural, psychologi-

Material published as part of this publication, either on-line or in print, is copyrighted by the Informing Science Institute and Preeminent Leadership and Research Solutions, LLC. Permission to make digital or paper copy of part or all of these works for personal or classroom use is granted without fee provided that the copies are not made or distributed for profit or commercial advantage AND that copies 1) bear this notice in full and 2) give the full citation on the first page. It is permissible to abstract these works so long as credit is given. To copy in all other cases or to republish or to post on a server or to redistribute to lists requires specific permission and payment of a fee. Contact Publisher@InformingScience.org to request redistribution permission. $\mathrm{cal}$, and political complexities of learning and the ways in which power complicates all human relationships (including those between students and teachers) mean that teaching can never be innocent. (p. 1)

Here, Brookfield highlighted several important points. First, critical education and its effects are often experienced differently by instructors and students. Second, although instructors may well

\section{Peer Blind Reviewed Research Article Editor: Crystal Chambers}

Submitted: April 4, 2016; Revised: June 4, June 25, 2016; Accepted: June 26, 2016 
anticipate and attempt to address this asymmetry proactively, there is likely no way to control the outcome(s) of critical education. Third, Brookfield grounds critical pedagogy in what Palmer and Zajonc (2010) called an 'epistemology of love,' or the idea that "we come to know best that which we love most" (p. 94). Although they were writing about a theory of knowledge, Palmer and Zajonc's notion of love, and its importance in the learning process, is consistent with Brookfield's commentary on the reason for forwarding critical pedagogy as a function of attempting to increase the amount of love and justice in the world.

However, critical pedagogy writ large is not without its malcontents. Not only is the process of critical pedagogy contested, but critical pedagogues have yet to reach consensus on what, if anything, critical pedagogy should $d o$. Elizabeth Ellsworth (1992) emphatically stated, "Critical pedagogues are always implicated in the very structures they are trying to change" (p. 101). Thus, it seems important for critical pedagogues to address not just what critical pedagogy is and strategies for it, but also one's aspirations for the results of critical pedagogy as well as what hope there is for achieving such results. Ellsworth's call to focus on the effects of critical pedagogy are far from cynical; in fact, she suggested that although the very thing one calls critical pedagogy has been misinterpreted and, thus, misused, it should not be discarded. Instead, critical educators should interrogate their own assumptions, attitudes, and behaviors regarding the work done alongside students in an attempt to arrive at a form of education hooks (1994) referred to as a 'practice of freedom.'

As critical pedagogues who teach in higher education graduate preparation programs, we wondered how the aforementioned contestations fit into our own practice working alongside graduate students in a one year Master's of Education program. Specifically, we sought to explore the thinking, teaching, and doing of critical pedagogy in a course focused on the history of US higher education. In order to explore these questions in more depth, we engaged in a co-constructed process of meaning making, known as duoethnography (Norris, Sawyer, \& Lund, 2012), which "is deeply personal and introspective; each scholar pushes the other to engage critically and reconceptualize their perceptions of the world around them" (p. 8). By reflecting upon a shared experience dialogically, we used the data of our experiences in the classroom to probe our understanding of transformative teaching - its inputs, outcomes, and practical and conceptual stumbling blocks along the way. The methodology requires us to understand ourselves as "the sites of the research, not the topics....[duoethnography] is a report of a living, dynamic, and collaborative curriculum" (Norris \& Sawyer, 2012, p. 13).

Taught over a six week summer term session and in two sections with a shared syllabus, the goals for the course, ED630G: Higher Education in American Society, included providing students with a foundational understanding about US higher education in an historical context, and to familiarize them with the key events and trends that have shaped higher education over the course of the last three centuries. US higher education has a long and rich history of expansion and growth since its inception in the 1600s. However, while in many cases this growth has led to greater inclusion and opening of access for more kinds of students from more identity groups and backgrounds, higher education in the US continues to be highly stratified, generally very costly, and thus elusive to many, particularly those of marginalized class backgrounds, genders, and racial/ethnic identities (Guinier, 2016; Mettler, 2014; Mullen, 2011). Critical inquiry into the root causes and conditions of this stratification are essential to the ongoing project of democratizing higher education (Gutmann \& Ben-Porath, 1987).

Students also engaged in critical conversations regarding the purpose(s) of higher education and how their views on this question may influence their role as future educators. Grounding the course in the notion that postsecondary education is essentially committed to the development of humanity (Berry, 1987), our aims were to join with students in considering what makes the college experience uniquely 'American;' reflect upon the traditions, practices, and values it has bor- 
rowed from its forebears in other nations; and (re)imagine educators' roles given the espoused values, purpose(s), and philosophy of US higher education.

Our aim in teaching this course was to infuse each aspect of the course's execution-class discussions and exercises, materials and texts, and assignments - with opportunities for students to be "critical co-investigators in dialogue with the teacher" (Freire, 1968/2000, p. 81), and, thus, to enable development of critical consciousness about US higher education. Seminal texts about the history of higher education (e.g., Rudy \& Brubacher, 1997; Thelin, 2011) often present major events and their effects in ways that elide the very real impact power has had on the experiences of subordinated groups, namely students and faculty of color, LGBTQ students and faculty, working class and poor students and faculty, and people with disabilities. In our efforts to enliven student knowledge about these effects, we consciously infused the course's structure and execution with dialogue. As noted by Shor and Freire (1987), "Through dialogue, reflecting together on what we know and don't know, we can then act critically to transform reality" (p. 13). Thus, one of our primary objectives was to create a classroom milieu in which students participated in sense-making regarding the current challenges facing higher education and the project of advancing democracy. The questions that guided our work were the following:

What does it mean to think, teach, and do critical pedagogy alongside graduate students in a Master's of Education program?

What are the (dis)connections between what we do as critical educators and how our actions are perceived by the students with whom we work?

What are the possibilities for using critical pedagogy to reimagine students' roles as future leaders of higher education?

\section{Literature Review}

\section{Critical Pedagogical Framework}

Critical pedagogy is an educational stance emanating from critical theory. Although scholars agree there is no solitary definition of critical pedagogy (Giroux, 2009; $\mathrm{M}^{\mathrm{c}} \mathrm{Laren}, 2009$ ), Lather (1998) articulated, "Critical pedagogy emerged in the 1980s as a sort of 'big tent' for those in education who were invested in doing academic work toward social justice" (p. 487). Whether called critical pedagogy, a pedagogy of hope (Denzin, 2009), education as the practice of freedom (hooks, 1994), empowering education (Shor, 1992, 1996), problem-posing education (Freire, 1968/2000), or critically reflective teaching (Brookfield, 1995), there are two central foci. The first focus is engaging students in being critical consumers of power, privilege, and knowledge, thereby helping them uncover what $\mathrm{M}^{\mathrm{c}}$ Laren (2009) referred to as the 'hidden curriculum.' Secondly, critical pedagogy requires educators to focus inward on their own assumptions, predispositions, and complicities regarding (in)equity and social (in)justice. For example, both Lather (1998) and Ellsworth (1992) called attention to the overwhelming preponderance of White male perspectives regarding critical pedagogy, signaling a complicity with White supremacy in neglecting the voices of critical pedagogues from marginalized communities

Kincheloe (2011) stated, "Too infrequently are teachers in university, student teaching, or inservice professional education encouraged to confront why they think as they do about themselves as teachers - especially in relationship to the social, cultural, political, economic, and historical world around them" (pp. 201-202). If teachers are not encouraged to situate what they know and value in the broader contexts in which they live, then it is likely they are not helping the students with whom they teach and learn to do so either; the effects of which are deleterious. In attempting to counteract the lack of critical reflection in education, Kincheloe (2011) suggest- 
ed, "A critical ontological vision helps us [students and teachers] in the efforts to gain new understandings and insights into who we can become" (p. 203). Similar to hooks' (1994) notion of critical education as a practice of freedom, proliferating the varied sources, understandings, and representations of knowledge is an investment in imagining the possibilities for a future built on equity, justice, hope, and love.

Although there are case studies focused on the implementation of critical pedagogy in higher education settings (e.g., Ellsworth, 1992), there is a paucity of work on infusing this educational paradigm in student affairs graduate preparatory programs. This is especially true for courses that do not deal primarily with issues related to power, privilege, and difference. However, the scarcity of such commentary seems particularly troubling due to the fact that student affairs, the field for which higher education graduate programs prepare future practitioners, is a profession that historically has been dedicated to the promotion of equity and social justice (Gaston-Gayles, Wolf-Wendel, Twombly, Ward, \& Tuttle, 2005; Komives, Woodward, \& Associates, 1996; Pope, Reynolds, \& Mueller, 2004; Sandeen \& Barr, 2006). Therefore, this oversight in the literature is in need of correction.

Although critical pedagogues take as axiomatic that the process of education is not neutral ( $\mathrm{M}^{\mathrm{c}}$ Laren, 2009), it is important to think beyond just critical reflection and engagement with course material to the effects of critical pedagogy itself (Ellsworth, 1992). In other words, educators need to attempt to answer the following questions: what are students to $d o$ as a result of critical pedagogy?; what are the material effects of a pedagogical intervention that foregrounds an agenda focused on increasing social justice and human dignity?; and is the process of critical pedagogy itself centered around the values of social justice and human rights, and dignity? The dual focus on etic and emic perspectives of education by critical pedagogues undergirds this paper's duoethnographic structure and resulting analysis.

\section{Method: Duoethnographic Inquiry}

Duoethnography is rooted in the desire to effect positive social change through the research process (Sawyer \& Norris, 2013). Although the methods of duoethnographic data collection are "emergent and uncertain" (Norris \& Sawyer, 2012, p. 25), the primary focus is on the dialogic exchange between two researchers who have different perspectives, backgrounds, and dimensions of personal identity. These reflections are then captured and infused into the narrative as part of the process of currere, or "an act of self-interrogation in which one reclaims one's self from one's self as one unpacks and repacks the meanings that one holds" (Norris \& Sawyer, 2012, p. 13). By focusing both on individual meaning and that made between researchers, duoethnography encourages one to recognize how culture and meaning-making reinforce and influence each other.

Precisely because duoethnography is inextricably linked to the promotion of positive social change, we found it served as a particularly relevant method of inquiry for exploring the enactment of critical pedagogy. Additionally, the dialogic nature of duoethnography allowed us to focus on the process of teaching critically in a way that highlighted both how we enacted critical pedagogy as well as the internal tensions, anxieties, successes, and/or possible effects of our efforts. Moreover, duoethnographic inquiry recognizes the potential of dialogue to expand the meaning researchers make of academic culture and their investment in that culture (Jones \& Calafell, 2012). As such, we used this particular mode of inquiry for its ability to allow us to explore further the multiple meanings we made both individually and together as critical pedagogues committed to promoting education as a practice of freedom (hooks, 1994).

Depth in duoethnography depends upon carefully considered elements that render it more than just a conversation - namely, a commitment to engaging with the stories of self and other in order to reimagine, rather than deify, understanding. Norris and Sawyer (2012) noted that "change and 
transformation are integral to duoethnography" (p. 18) and that through this process we come to understand ourselves and our practices differently. It is also true that duoethnographic dialogue is most ripe for revelation when partners differ in some fundamental way. In the case of this project, Z's identities as a queer, able-bodied, White, femme-of-center trans* [Definition of these terms can be found at http://itspronouncedmetrosexual.com/2013/01/a-comprehensive-list-of-lgbtqterm-definitions/] person inevitably portend different perceptions and reflections than Susan's, as a white, 45-year old, lesbian and feminist.

To conduct the duoethnography, we engaged in a multistep process whereby we used the experience of teaching the same course - albeit in different rooms, with different students - as the basic material of our inquiry process. The six week, 36-hour course was structured to engage students in three distinct tasks: to understand (and engage critically with) the history of higher education in the US from 1636 to the current day; to make meaning of current challenges to the democratic realization of higher education; and to apply problem-solving approaches to college access for students of varying class backgrounds and social identities in college. Each week, we conducted class discussions and exercises, intentionally framing specific topics of inquiry critically. On four different occasions, we recorded our individual reflection on that evening's teaching and learning experience, sharing moments of triumph, scintillation, engagement, and anxiety about the critical stance we were attempting to take in our teaching. Adopting the mode of analysis exhibited by Krammer and Mangiardi (2012), we reviewed these sessions, revisiting them individually and together to reflect upon the effect the stories had on our evolving sense of self as critical educators.

\section{Duoethnographic Dialogue}

In order to engage effectively in a duoethnographic dialogue, the authors created an audio recording after four specific class sessions where they maintained an ongoing dialogue debriefing the experience of teaching the course, noting any important 'critical moments' in their (separate, but concurrent) course section meetings. In this way, the data (reflections) become the ethnographic basis, which then informs the process of engaging with them together as a duoethnography. We then reviewed the recordings in their entirety in order to inform construction of the dialogic reflection, the heart of the duoethnographic experience, which appears below. This dialogue was based on both the authors' experiences in the classroom as well as the post-class session conversations they had during their teaching of the class. This method "follows the model of representation in duoethnography; that is, a text written as a dialogue between two people, without merging or subsuming two voices or perspectives (co-authors) into one coherent text, and without relying or drawing extensively on exterior voices or texts for substantiation" (Seidel \& Hill, 2015).

The conversation starts with an exploration of why the authors decided to teach the history of higher education from a critical perspective and explores issues related to how time influences pedagogy, the role and effects of social identities on learning, and negotiating between the process and product of education.

[Z]: When I think about the history of higher education courses I have either taken or discussed with colleagues, I hear similar stories of learning about the largely well-off White men who saw U.S. higher education as a 'finishing school' for gentlemen. However, what continues to be missing for me are discussions of marginalized students in higher education; students with subordinated racial identities, Lesbian, Gay, Bisexual, Transgender, and Queer (LGBTQ) students, students from low socioeconomic class backgrounds, students with disabilities, and women. The seeming lack of these students from the history books, coupled with several marginal personal identities that are salient, make me think it is important to uncover and reclaim the history of these students in higher education. We know, or can at least say with some sense of certainty, that marginalized students were indeed historically present, so why not talk about them? At the very least, we 
should be pointing out their visible absence from the current literature and wondering aloud with students why they are not there.

[SUSAN]: I share your sense that there are missing voices and experiences from the histories that have been published to date. I vividly recall being in classes addressing higher education history in my Master's program and wondering how and why certain narratives were privileged, to the exclusion of others. I wanted a fuller sense of what women, students of color, LGBTQ students, and low-income students brought to the shaping of institutions and educational practices. So many scholars now center these voices, but 20 years ago, this was less common. I think I would have been a different kind of practitioner earlier in my career if I had been exposed to this history through a critical frame. I hope to give my students what I see as a real advantage - the ability to question, and comfort with questioning from the beginning, what we take to be true about college. I think it's an essential part of their toolkits to effect change in student affairs.

[Z]: You raise an interesting point when you mention that you may have been a different kind of practitioner had you been exposed to the history of higher education through a critical lens. I wonder how much of our desire to hear, listen to, and uncover the voices of marginalized student populations has to do with our own marginalized identities. Moreover, I wonder how much of our interest in teaching the history of higher education critically may also stem from the realization that we knew there would be students in our classes wondering, "Where am I in this history?" This was a question I remember asking, and wonder if this was the same for you. A colleague of mine once told me that there is always at least one student who needs us as instructors to be ourselves. For me, this means both showing up with all of my identities (marginalized and privileged), openly interrogating who is present and absent from historical texts, and working alongside students to grapple with the reason(s) for their presence and/or absence.

[SUSAN]: Interestingly, I don't recall wondering where I was in the dominant historical narrative because the way I was taught about it de-emphasized the almost complete absence of women of any race until the 1830s. I was a bit gobsmacked to learn, in my doctoral program, that I was in fact absent for the first 180+ years of higher education - let alone thinking about myself as a lesbian. I agree that students need us to show up as we are and to center our identities so that they may feel more comfortable centering themselves also. But the tricky thing is, when we are missing or absent from narratives, how do we correct that? If the text isn't there, it isn't there. Yet we know we were there. So how can we help students see beyond-and think beyond-who is in the dominant narrative, without creating fictitious accounts? And how do we do that when we really don't have access to these histories. It seems to me we have to think about ways to 'center the missing' without fictionalizing.

[Z]: I like how you posed this challenge of centering the missing without fictionalizing. I certainly am not in favor of revising history by creating fictional narratives. However, I have often 'centered the missing' by posing the questions, who is missing from this history? whose voices are not present? and if we know these populations were present throughout society, why might they not be represented throughout the history of U.S. higher education? Thus, rather than actually locating narratives, I have interrogated the absence of these narratives in the context of higher education juxtaposed with the social reality of the populations themselves. It becomes a bit of a thought experiment, but has been a powerful tool that does two things. First, it helps students develop an understanding of history as a socially constructed field influenced by systemic oppression and privilege. Secondly, I feel like asking questions and not having answers helps students take more ownership in the classroom. They become more invested in the educational process because they understand I am not going to fill them up with facts that they will then need to recite back to me. In other words, by asking tough (and in some ways unanswerable) questions with students, we begin to move away from what Freire called the 'banking model' of education. 
[SUSAN]: I admit I've struggled over the years with balancing the critical stance and the 'banking model.' There's part of me that wants students to have the foundational knowledge of our field, so that they can bring the knowledge of history - with all of its myriad oppressions and absences - to their current work. Then one day recently, I had an epiphany. I'm cleaning out binders for classes I took during my doc program, and I had little or no recall memory of the content of these courses-law, policy, org theory, etc. What I can say I recall is the ways these courses taught me to think about problems in higher education, how to deconstruct interlocking causes and contributory factors and analyze them for alternatives. And more and more, this is what I want our classrooms to be about - ways of thinking and analyzing problems, toward solutions that are more just and inclusive. So I'm trying to shift the balance of 'depositing knowledge for the sake of fact recitation' to 'providing knowledge so that it can serve as context for critical analysis.'

[Z]: That is a really powerful insight about course content and ways of thinking through the cultures, problems, and opportunities for growth in higher education and student affairs. I agree this is important, but remains a bit elusive to me. In thinking about our experiences teaching last summer, I sometimes felt I went too quickly to handing students information rather than inviting them to make sense of it with me. I rationalized some of this by telling myself it was many of the students' first graduate-level course, but I think this was just an easy out for me. After about four weeks, I felt comfortable inviting the students to make sense of the material with me rather than my doing it for them. When I did this, I sensed more excitement in the classroom. The students seemed to be more curious and inquisitive, and they seemed better able to handle the ambiguity that came along with some of the questions we were asking of the texts and each other. I am not sure what prompted this shift for me-perhaps I let go of an irrational sense of needing to be seen as an 'expert.' Or maybe there needed to be some time before students felt comfortable taking a more active role in their education - but I was pleased to see some tangible changes in thinking (e.g., they asked great probing questions) and behavior (e.g., they would talk to each other rather than directing comments solely to me).

[SUSAN]: What you're describing seems to me to relate back to what we've talked about before- the function of time in the critical classroom. How time acts as a facilitator or barrier to critical learning. I'm curious about the four week mark of a six week course. Something happened that led you to feel like you could approach the learning process differently with students - inviting them in to the analysis, as you said, rather than framing it for them. I'd love to hear more about how you perceived this shift and then moved forward into a different mode of relating to them and to the teaching process. What were the signposts of readiness, and how did you engage the students? I'm guessing trust was a factor; you had to believe they were ready and had done the prep work to begin to apply a critical lens to the work. And in a six week class, how do we know when we've crossed that threshold?

[Z]: You're right in saying there is something about time (and timing) when I conceptualize my role as a critical educator. I think it is neither fair nor prudent for me, as a critical educator, to expect students to be able to engage in non-banking models of education from week one. This is especially true in the case of the course we taught, as it was the first graduate level class for many of the students. Additionally, I think it is likely that many, if not most, students may not have ever experienced critical education previously. Because of this, I wanted to take a stepwise approach to critical engagement. I did this in subtle ways (e.g., sitting in a circle with students, inviting them to direct comments to each other rather than me, being silent and encouraging students to instigate dialogue among themselves) as well as overt methods (e.g., small group and large group discussions, reflecting questions asked to me back to the class, and, after four weeks, inviting students to lead discussion about the texts rather than beginning by walking them through what I deemed to be 'important points' to understand). 
I'm not convinced there is any way to figure out that students are 'ready' for sharing more responsibility in the classroom, but I do think that after seeing an increase in students' critical thinking and heightened investment in asking questions of the texts and each other, I was more willing to give it a go. Also, it took me some time to feel comfortable 'letting go' as an instructor. Some of this is related to insecurities I have that are likely based on my being a relatively young educator-I was less than 10 years older than some of the students, and look far younger than the conventional image of a 'professor' - as well as being a trans* educator, which has previously led some other students with whom I have worked to question my abilities in the classroom. I also think my status as an adjunct instructor made me hesitant to cede some control, because I felt the need to convey to students that I had been brought in to teach the course due to my skill set (something I feel may not necessarily happen once I get my $\mathrm{PhD}$ or have a tenure-track position). So there are some external strategies I used, but also some comfort I gained throughout our first month in the classroom in negotiating some internal identities. What about you? How do you know when it is the 'right time' to implement critical pedagogical practices? How do you think about your multiple identities in relation to this process?

[SUSAN]: I think for me it depends on the degree of comfort I have with the students and they with me. For example, I am much more confident and comfortable utilizing critical stances and approaches with students this semester, after knowing them for one semester and getting a sense of their readiness and comfort levels with approaching the edge of the learning process (meaning, taking the chance to interrogate the material, the social and cultural effects of various kinds of oppression). This feels like 'the edge' to me because it does entail risk - as you said, being able and willing to 'let go' of my sense of myself as an authority/leader, and engage them in the process of analyzing the material and the topics we're discussing in class. It means there are times when we won't have the answers - and in particular, I won't have the answer, which is something I think that students expect and I admit that I take some measure of gratification in having those answers - that is, after all, what we spent all those years studying for, right? I think my identities are wrapped up in this to some extent. Having spent much of my time during my graduate program reading the research about women's presumed incompetence as academics, as knowledgebearers, I probably carry some anxiety about that with me. I think being older now than when I began helps in my confidence. I feel like with each course, each new group of students, I do a subtle form of calculus to determine if we can 'go there,' and if so, how much, and when.

[Z]: I completely agree that determining when, how, and if I as an instructor can 'go there' with students can be risky business. However, the notion of time in relation to engaging in critical pedagogy makes me wonder, if we as instructors only have a limited time with students, when do we take those risks? And, in considering when we take them, what are we willing to potentially give up (e.g., students' trust, harmonious class spaces, students' perceptions of our approachability) in order to 'go there'? Whether we work alongside students for six weeks in a summer course, 14-15 weeks in a semester, or one to two years in a graduate preparation program, I feel the press of time as a critical educator. I don't think there is any 'right' answer here, but do you ever worry that if you as a critical educator don't 'go there' with students, then they may not experience this type of education — which I think we agree is incredibly important - elsewhere?

[SUSAN]: Such an important thing you're pointing to here. If we acknowledge that we have a responsibility to engage in critical dialogue with our students, but we 'wait' until it feels that the time is right, do we undercut our ability to spend more time on the analysis from a critical stance, and to truly allow the learning process - the struggle it may entail - to play out? Somewhat crudely, in the history class, I've always considered learning to follow a bit of a cycle. First, I introduce new ideas and constructs. Next, I invite students into the work of analyzing different perspectives - the time and work it takes to earnestly seek out the 'truth' together of various assertions about those events and their impact. Then and only then are students ready to apply the 
learning in a new problem-solving situation. We followed this pattern frequently this summer. So the question is, how does this assumption impact our ability to 'move things along' and get our students to the critical questions, sooner? Did we allocate the time appropriately for both the banking style of learning and the critical questioning to take place? What could we have let go in order to get to the critical piece sooner, if anything?

[Z]: I really appreciate that you see the banking model of education and critical pedagogy as a both/and notion. I have often thought it a bit myopic to say that banking education has no place in the classroom. Surely one has to develop a foundation of knowledge in some sense before one can be critical of that foundation, right? However, I wonder if there is a way we might be able to frame the beginning exploration of knowledge through students' interests and perspectives? What I mean by this is we could invite students in the first week to think of several questions through which they want to address the history of U.S. higher education. Perhaps this takes place through a short, low-stakes assignment like a reflective essay that couples their experiences in higher education with what they want to know more about the environment from an historical stance. In this way, students are able to pose critical questions from the start of their educational experience that are then carried throughout the course. It is also something they own, as it comes from their own experiences and perspectives. It also provides a stepwise approach to critical pedagogy in which exploring how privilege and power have shaped the landscape of U.S. higher education throughout its history. Of course, I am also curious about the idea of course sequencing. At the end of our time teaching last summer, we discussed the possibilities of requiring students to take the Diversity and Social Justice course in your program before (or even concurrently) to taking the History and American Society course. By having the Diversity and Social Justice class as the first class experience in their graduate education experience, students would get to develop and practice a critical toolkit they could carry with them throughout other courses and, by extension, into their jobs as educators. How important do you think course sequencing for achieving the goals of critical pedagogy?

[SUSAN]: Great question, Z. I think we'll have a chance to see as some or many of the students will likely take Diversity and Social Justice before (or while) taking the history of higher education course next summer. It could be very interesting to see how they make those connections across the courses. I like the idea about asking them to generate the questions they'd like to answer as a result of their own experiences. Is it cynical that I think they won't think as deeply or as far back as we might hope - all the way to the foundations, the beginnings? As much as my over emphasis on the Ivies and the UVAs at the start of the course might not be terribly engaging for a group of students who went to places like Fitchburg State and UMass, I can't shake my sense that it really matters that they know the origins of US higher education were classist, racist, and sexist to an extraordinary degree. I wonder if any of them would ask a question like, 'why does race continue to be a factor in college access/equity?' but that's the kind of question I wish/want them to ask. If I let go and let them direct the focus, will that compromise what I think they need to learn to be effective critical educators? And can I trust the process to know that they will, organically, generate these questions on their own? I guess it comes down to what is essential, foundational, and at the core of any meaningful engagement with higher education's history. How do we decide?

[Z]: I don't think you are selling students short at all. You have a deep investment in their learning, specifically their learning about how the historical oppression in U.S. higher education plays a continuing role in shaping students' experiences today-including theirs. This makes me realize that it is not only our identities that influence the learning community, but students' identities as well. In other words, it is just as important to help surface and process through how students' identities 'show up' across time and space when talking about the historical foundations of higher education (or any subject, really). If we are able to do this, not only do we help create buy in- 
students can see where they do and/or don't fit into the larger context—-but students also begin to think more critically about what this all means for what is currently happening on college and university campuses; something we both ask students to be pretty deliberate and thoughtful about toward the end of the course. Your comments also make me think again about how to combine the notions of process and product. For example, if we believe as critical educators the process of education is important (e.g., developing critical thinking skills, learning how to engage with texts, seeing issues from multiple perspectives), how do we do this while also focusing on the overall products of the class (e.g., final papers, helping students understand the ideas which we deem to be foundational and essential to their work as educators)? Is there a way to negotiate this successfully, or are we always bound to feel like we mucked it up? And if so, is there a latent potential in our failure? In other words, what would happen if we start from the position that we may not get the negotiation 'right,' but we are committed to doing our best in focusing on both the product and process of education, in whatever constellation that may take? I feel like an undercurrent of our conversation has been the assumption that we need to be the Best Teachers, but what if we recognized our fallibility and embraced the potential that we may fail? Is there potential in that failure?

[SUSAN]: I love the possibilities in what you are talking about here. I do think there is value in permitting the process to be the focus, rather than the product. It entails risk, but it also opens the door for students to have a 'click' moment, to recognize the lived experience of themselves or others in a different way. While the goal of any course always feels a bit elusive to me, what if we agreed that in the critical classroom context, we are specifically looking to facilitate those click moments, those new realizations, rather than focusing on ensuring that our get all the content, commit it to memory, and spew it back to us in papers? If we can agree that a discernible shift in perspective is the goal, it makes our jobs both harder and easier. We can let go of the need to be seen as authority, as the 'sage on the stage,' while at the same time having to own the reality that measuring that shift is more complex than testing students' knowledge banking. I can visualize asking students to write at different points in the summer about what's changing for them, what they now understand about higher education that they didn't before. Then tracking their knowledge, their awareness as it is unfolding. Could you imagine doing this? Could we then know better if the students are becoming critical in their own right?

[Z]: In the courses that I am currently teaching, I've actually been experimenting with some assignments that do the very things about which you are talking. Specifically, I am attempting to reinforce the notion of learning as an iterative and lifelong process as well as the idea that learning happens best in a supportive community of peers. For example, in one course I am teaching, I ask the students to submit weekly journal reflections that are based around the same prompt: how have the readings and class discussions this past week influenced your thinking on masculinities (the topic of this particular course)? In this way, students can, through the course of the semester, begin to see their own arc of thought. They also get an appreciation for both iterative process of knowledge construction as well as synergistic relationship between classroom learning and their lived experiences. In another class I am teaching, I have asked students to commit to regularly posting questions, comments, thoughts, and external links and connections to course topics on a shared document (we are using a shared Google Doc). I also take part in this activity, and it has been fascinating to see students work alongside each other in virtual space to really explore the readings and course topics. Admittedly, these are both evaluative measures (they are, after all, assignments for which students are earning credit), but they reinforce connection rather than individualism and lifelong learning over mastery. I also find these assignments have helped unseat the notion that my job as an instructor is, as you so wonderfully put it, to be the 'sage on the stage.' 
[SUSAN]: Great approaches, Z. It seems clear that when you ask students to engage with each other outside of the classroom, you're also saying 'the collective learning continues, even when we are not all in the same room." I wonder if these kinds of strategies are amenable to critical inquiry as well. If we buy the premise that de-centering ourselves as the only authority in the classroom is a good idea, then how can we make sure that students also take up this responsibility in a way that feels possible for them (I'm thinking here about the kinds of authority students seem to embody when they are doing class presentations at the end of the term, and whether and how that sense of ownership not only for their own but for others' learning could be nourished earlier in the term). I think one way is to encourage them to use their "I voice" in shared assignments. Another might be to make sure that shared-document questions have a critical edge to them. Centering power in their analysis, and the deconstruction of it.

[Z]: I sometimes worry that as a critical educator, I run the risk of being seen as 'having an axe to grind.' In fact, I have received this feedback on course evaluations and feedback forms. What risks do we run in the doing of critical education, especially with students who have dominant salient identities? Have you experienced this? If so, how do you resolve it in a way that makes you feel comfortable continuing to agitate for change as a critical educator?

[SUSAN]: I think this is very real, and to be truthful, I don't think it's always an unfair critique. The material, the content itself, is all new to the students, and yet in addition to wanting them to understand it and integrate it into their thinking and practice, we also want them to apply critical inquiry to the issues at the same time. And in that process, we often can't or don't attend to the affective reality of critical inquiry - they are likely having feelings about coming to terms with privilege and oppression, in themselves and others, but do we make time or space to talk through those feelings, to create space for their process of coming to terms with these inevitably painful and sometimes even shameful realizations. I won't speak for anyone but myself, but I rarely do make space for that, as we discussed, since I feel so crunched for time. I think the leap we are asking of them, in terms of how we are asking them to think, in a pretty significant one - and I'm not sure we always make time or space for processing that.

[Z]: The themes we continue to circle back to - time, affect, 'productivity,' the multiple experiences of self and students in the classroom - seem inextricably linked to both Monan's (2009) and Nussbaum's (2010) views on liberal arts education, which we use to frame our class! That is, the historical notion that educators dealt only with a student's intellect, which Monan discussed, or that our role as educators is to fill students with facts so they can be passive and 'productive' citizens, which Nussbaum highlighted, are exactly what we are experiencing. It seems that history is repeating itself...or perhaps there is just more work to do in addressing it (and teaching it) critically. At the end of the day, I guess I am comfortable giving up some of the 'facts' to spend more time making sure students can practice critical thinking and engagement. It doesn't make things easy, or linear, or comfortable all the time, but it does seem like the best way forward to me. After all, a student can always look up a date they may forget...something that cannot happen with critical inquiry skills. Am I being too pie-in-the-sky in this view?

[SUSAN]: Not at all. Ultimately, critical inquiry is by turns utopian while also being grounded in the here and now. I think we must be willing to be open to what learning looks like in all its permutations - does it matter more that UVA and Harvard were among the first colleges, or that students can actively describe the systemic inequality that shaped each of their histories? I think we'd both concur that they can do the latter, and if it comes at the expense of time spent on the former, so be it! I think this means that we also have to really carefully interrogate the materials we use. Thelin's (2011) history, while carefully composed and documented, does not carry the feel or impact of a critical analysis of higher education history; Nussbaum (2010) certainly engages with the questions, but in a perhaps more abstract and current way than we can or should lead off with in such a course. So the next question is, do we have accessible, meaningful docu- 
ments at our disposal? Or is our only choice to begin composing our own 'people's history'? Are the materials really essential, or are there other ways we can on-ramp their learning, other tools, other (better) media we can employ?

[Z]: I like your thinking about how we as educators can provide on-ramps for students. This remains a challenge for me, especially given my desire to engage in an educational environment geared toward equity, justice, and what hooks (1994) referred to as a 'practice of freedom.' How we on-ramp students becomes all the more important when thinking through the other classroom realities we have discussed, specifically the influence of time, social identities, and the multiple ways our classrooms are experienced. Although we may never arrive at answers for every situation that comes up, the critical pedagogue in me says that the very act of asking and discussing is meaningful in and of itself.

\section{Discussion}

The previous duoethnographic dialogue extends several themes relevant to current literature. Specifically, these include connections to the role and influence of neoliberalism in higher education as well as the varied effects of social identities for educators and students in attempting to enact critical pedagogy. Additionally, this connects to several seminal documents within the fields of higher education and student affairs (e.g., the Student Learning Imperative (Astin et al., 1996), Learning Reconsidered (Keeling, 2004), Learning Reconsidered 2 (Keeling, 2006)) about addressing student development from a holistic perspective both in and out of the classroom. Although this sounds good in theory, it becomes much more difficult to put into practice. Overall, these discussion points connect to Ellsworth's (1992) call to focus on the doing of critical pedagogy. Thus, rather than reasserting the need and benefits of engaging in critical pedagogy, we take up Ellsworth's charge to explore critical pedagogy as praxis, or as the process of putting a theoretical perspective (i.e., critical pedagogy) to work.

Harvey (2007) described neoliberalism as "a theory of political economic practices proposing that human well-being can best be advanced by the maximization of entrepreneurial freedoms within an institutional framework characterized by private property rights, individual liberty, unencumbered markets, and free trade" (p. 22). Furthermore, where no markets previously exist, as in the case of education, neoliberal logic posits markets "must be created, by state action if necessary" (p. 23). Therefore, even those social institutions deemed public (e.g., education) are made private by way of a neoliberal agenda. This is extremely relevant when looking at higher education, as Heller (2011) noted that $80 \%$ of the college going population matriculates at public universities, which are the very same public institutions that are being transformed by the market logic of neoliberalism.

Along with a reliance on market logic, neoliberal perspectives on education focus heavily on measures of productivity, effectiveness, and efficiency. Tuchman (2009) suggested this new managerialism was to the detriment of the academy and those who operate within its environs. As evidenced in the previous dialogue, the notion of time, never having enough of it, and needing to make decisions about content as a way of being efficient in the classroom and providing a productive learning experience weighed heavily on our minds. Furthermore, it is impossible to divorce one's critical epistemological and pedagogical values from the effects of holding these values on such standardized forms of 'effective teaching' such as teaching evaluations. Given that these remain the gold standard upon which in-class teaching is measured and they have the ability to influence hiring, tenure, and promotion decisions, critical pedagogues who might be labeled as 'biased' or 'having an axe to grind' by students potentially stand to lose much.

In relation to critical pedagogical praxis, this text underscores that the social identities educators and students hold have a direct impact on the learning community into which they enter. Critical 
theorists such as Patricia Hill Collins (2000), bell hooks (1994), and Kimberlé Crenshaw (1989, 1995) emphasized that who we are has a direct impact on how we experience the world and how we come to know what we know. In fact, feminist standpoint theorists (a grouping of which Collins is a part) contended that it was impossible to approach knowledge - and by extension one's own learning - without taking one's social identities into account. Not only do our social identities influence how we teach, or how we learn, but our social identities produce effects in the world. Understood from a classroom perspective, identities are not just internal markers that one holds onto, but are experienced by others around us. By extension, teaching and learning in a critical classroom is affected by the various social identities of those in the setting (e.g., students and educators). Far from being a normative judgment suggesting a 'good' or 'bad' evaluation, knowing that these identities influence the educational process suggests one might want to be attentive to these dynamics. For example, we both experienced times when race was invoked in the classroom and students with subordinated racial identities felt the need and/or desire to speak from their personal experience. Additionally, one of us struggled with our role as 'correctors' of awkward or hurtful language, which was made more complex due to students' newness to the program and the instructors' desire not to risk shaming the student so early in their relationship. There is much to be gained from these personal narratives, but they can also be perilous, as students may feel they are forced to speak for their race and/or others may understand their narratives as indicative of their racial group. In these moments, our blunders as critical educators (Tassoni \& Thelin, 2000) have the potential to impose significant personal harm, as students may feel they are being reduced to a singular identity or experience and are only as good as their ability to speak on behalf of 'their people.' In all cases, however, the effects of our identities - in this example, race - have a direct impact on our learning community that cannot — and should notbe avoided.

Several seminal documents in the field of higher education and student affairs espouse taking one's social identities into account when addressing student learning and development. Works such as the Student Learning Imperative (Astin et al., 1996), Learning Reconsidered (Keeling, 2004), and Learning Reconsidered 2 (Keeling, 2006) tout the importance of viewing student learning in and out of the classroom from a holistic perspective. Despite the rhetoric, however, putting this into practice remains tricky at best. Not only is a holistic approach to education messier than conventional approaches in which educators address students as intellectual beings (Monan, 2009), it also takes additional time and intention. As noted above in the discussion of neoliberalism, however, both of these are transformed into precious commodities which educators may be encouraged not to relinquish easily, if at all. Thus, despite the call to approach student learning from a holistic perspective by focusing on both the process and product of education, there are many factors - systemic and otherwise - dissuading critical educators from doing so.

\section{Implications}

Norris, Sawyer, and Lund (2012) cautioned that duoethnographies "do not end with conclusions. Rather, they continue to be written by those who read them" (p. 21). Although we concur, we also believe there are implications one can draw from the previous dialogue. Specifically, critical educators attempting to build classroom environments with the potential to be liberatory face numerous challenges, such as the pressures of limited time to develop foundations of knowledge from which critique can unfold and the complex and layered power dynamics of the social identities circulating in the critical classroom. In such a labyrinth, it is essential for critical educators to consider the costs and benefits associated with balancing the both the process and the product of education. Clear yet supple objectives for the knowledge which students will be asked to gain, and the skills of critique we aim to foster, must be front and center, and revisited consciously as the class dynamic (including the dynamics created by students and teachers' social identities) sur- 
face. This is certainly a weighty endeavor, but is also one from which critical pedagogues should not hide.

While in our dialogue we clearly grappled with the realities of neoliberal curricular frames, our experience suggests that it is incumbent upon critical educators to make principled and courageous decisions in this realm, and that the power of the critical classroom depends precisely on our resistance to neoliberal 'standards' and their exposure to the light of day. To this end, we must consider: What might be gained from inviting our students into the process of defining course goals and objectives, rather than relinquishing our authority to the illusion of the 'knowledge checklist' that banking models of education demand? Can we, in extending greater trust and partnership with our students, relax into the reality that they may 'know less,' but do more, with the experiences gained in the critical classroom? We suggest that the gamble is worth the bet.

Additionally, our experience suggests that there is great value to be gained from the process of reflexivity. We advance the proposition that even more so than in a traditional classroom, we are called to reflect upon our work, and our failures, as co-conspirators in teaching and learning (Flannery, 2006). We propose that not only will this strengthen the critical classroom, but indeed, will enliven the learning experience for graduate students, who are frequently primarily motivated by the desire to gain 'marketable skills' in the graduate classroom. By modeling reflexivity in ourselves, and encouraging its practice in students, an alternative to having and transmitting the 'right answer' emerges - one that while momentarily destabilizing, we maintain will be ultimately more 'valuable' to the learning process.

Because this study was centered on transformational pedagogies, we engaged reflexively in modifying this course for subsequent iterations as a result of the insights gleaned from the duoethnographic process. Specifically, we made the course more active by "flipping" it (Stone, 2012), using course time for focused application of concepts rather than using the time for lecture, eschewing the 'banking' model of education. We engaged the students more actively in taking ownership in the classroom by asking them to name the emergent questions they were most excited by at the start of class sessions, and requiring them to present and interpret concepts and data more consistently throughout the course. Finally, we have abandoned use of traditional historical texts, such as Thelin's (2011) and Rudy and Brubacher's (1997) histories of higher education, so that more critical texts can be used as the foundation for learning. These include Criag S. Wilder's Ebony and Ivy (2014), Lani Guinier's The Tyranny of Meritocracy: Democratizing Higher Education in America (2016), and Patton's Disrupting Postsecondary Prose: Toward a Critical Race Theory of Higher Education (2015).

Ellsworth (1992) critiqued critical pedagogues for perceiving themselves to be outside the scope of inquiry. In other words, despite talking about dismantling systems of privilege and oppression, critical pedagogues may not practice in a way that is consistent with their theoretical viewpoints. However, pedagogical interventions to establish and create personal investment on behalf of students, as well as those that encourage students to explore their own complicity with systemic oppression, only attend to one aspect of being a critical educator. Of equal significance is that the actual doing of critical pedagogy also increases social justice and human dignity. Ellsworth issued her call for critical pedagogues to reexamine their classroom practices more than two decades ago, and still some educators who identify as critical are reticent to truly enact and reflect upon this theoretical orientation.

\section{Conclusion}

'Credential inflation' (Pappano, 2011) is shaping the belief that the master's degree is the new requirement for obtaining steady employment in a neoliberal economy. As a result, graduate 
school is viewed as a necessity by more and more students. Master's education has been traditionally viewed solely as professional preparation. However, we assert that more is possible; that we can and must infuse the graduate experience with innovative opportunities for critical consciousness building.

To this end, our duoethnographic dialogue provided us as activist educators with an occasion to engage in 'a 'defiant speech' that is constructed within communities of resistance and is a condition of survival" (Ellsworth, 1992, p. 102). In keeping with our critique of our teaching in this study, we maintain that higher education graduate programs must prioritize the process as well as the product of the foundational history course. It is not enough to deliver information; we must empower students to interrogate their (and others') positionalities and the ways in which privilege and marginality interact to inform our critically conscious practices. We concur that "critically minded people, scholars and citizens, must move beyond an individualized location, expanding their accountability from self, to others and self' (Jones \& Calafell, 2012, p. 976). Thus, we see our roles as critical pedagogues as not only encouraging a future generation of educators to work toward equity and the continued expansion of opportunities and access to higher education, but also as a commitment to ourselves and other critically-minded peers. Ultimately, we echo Ellsworth's (1992) claim that the reflexive analysis of enacting critical pedagogy is just important as espousing why and to what end one should do it.

\section{References}

Astin, A., Astin, H., Bloland, P., Cross, K. P., Hurst, J., Kuh, G., ... Schroeder, C. (1996). The student learning imperative: Implications for student affairs. American College Personnel Association. Retrieved from http://www.myacpa.org/sites/default/files/ACPA\%27s\%20Student\%20Learning\%20Imperative.pdf

Berry, W. (1987). Home economics. New York, NY: North Point Press.

Brookfield, S. D. (1995). Becoming a critically reflective teacher. San Francisco, CA: Jossey-Bass.

Collins, P. H. (2000). Black feminist thought: Knowledge, consciousness, and the politics of empowerment (2nd ed.). New York, NY: Routledge.

Crenshaw, K. (1989). Demarginalizing the intersection of race and sex: A black feminist critique of antidiscrimination doctrine, feminist theory, and antiracist politics. The University of Chicago Legal Forum, 1989, 139-168.

Crenshaw, K. W. (1995). Mapping the margins: Intersectionality, identity politics, and violence against women of color. In K. Crenshaw, N. Gotanda, G. Peller, \& K. Thomas (Eds.), Critical race theory: The key writings that formed the movement (pp. 357-383). New York, NY: The New Press.

Denzin, N. K. (2009). Critical pedagogy and democratic life or a radical democratic pedagogy. Cultural Studies <=>Critical Methodologies, 9(3), 379-397. DOI: 10.1177/1532708609332607.

Ellsworth, E. (1992). Why doesn't this feel empowering? Working through the repressive myths of critical pedagogy. In C. Luke \& J. Gore (Eds.), Feminisms and critical pedagogy (pp. 90-119). New York, NY: Routledge.

Flannery, J. (2006). Teacher as co-conspirator: Knowledge and authority in collaborative learning. New Directions for Teaching and Learning, 59, 15-23.

Freire, P. (2000). Pedagogy of the oppressed. (M. Ramos, Trans.). New York, NY: Continuum. (Original work published in 1968.)

Gaston-Gayles, J., Wolf-Wendel, L., Twombly, S., Ward, K., \& Tuttle, K. (2005). From disciplinarian to change agent: How the civil rights era changed the roles of student affairs professionals. NASPA Journal, 42(3), 263-282. 
Giroux, H. A. (2009). Critical theory and educational practice. In A. Darder, M. P. Baltodano, \& R. D. Torres (Eds.), The critical pedagogy reader (2nd ed.) (pp. 27-51). New York, NY: Routledge.

Guinier, L. (2016). The tyranny of the meritocracy: Democratizing higher education in America. Beacon Press.

Gutmann, A., \& Ben-Porath, S. (1987). Democratic education. John Wiley \& Sons, Ltd.

Harvey, D. (2007). A brief history of neoliberalism. Oxford, England: Oxford University.

Heller, D. E. (2011). The states and public higher education policy: Affordability, access and accountability (2nd ed.). Baltimore: Johns Hopkins.

hooks, b. (1994). Teaching to transgress: Education as the practice of freedom. New York, NY: Routledge.

Jones, R. G.. \& Calafell, B. M. (2012). Contesting neoliberalism through critical pedagogy, intersectional reflexivity, and personal narrative: Queer tales of academia. Journal of Homosexuality, 59(7), 957-981.

Keeling, R. P. (Ed.). (2004). Learning reconsidered: A campus-wide focus on the student experience. The National Association of Student Personnel Administrators \& The American College Personnel Association. Retrieved from http://www.naspa.org/images/uploads/main/Learning Reconsidered Report.pdf

Keeling, R. P. (Ed.). (2006). Learning reconsidered 2: Implementing a campus-wide focus on the student experience. The American College Personnel Association, Association of College and University Housing Officers-International, Association of College Unions-International, National Academic Advising Association, National Association for Campus Activities, National Association of Student Personnel Administrators, and National Intramural-Recreational Sports Association. Retrieved from https://www.nirsa.org/docs/Discover/Publications/LearningReconsidered2.pdf

Kincheloe, J. L. (2011). Critical ontology: Visions of selfhood and curriculum. In K. Hayes, S. R. Steinberg, \& K. Tobin (Eds.), Key works in critical pedagogy: Joe L. Kincheloe (pp. 201-217). Rotterdam, The Netherlands: Sense Publishers.

Komives, S. R., Woodard, D. B., \& Associates (1996). Student services: A handbook for the profession (3rd ed.). San Francisco: Jossey-Bass.

Krammer, D., \& Mangiardi, R. (2012). The hidden curriculum of schooling: A duoethngraphic exploration of what schools teach us about schooling. In J Norris, R. D. Sawyer, \& J. Lund Duoethnography: Dialogic methods for social, health, and educational research (pp. 41-71). Walnut Creek, CA: Left Coast.

Lather, P. (1998). Critical pedagogy and its complicities: A praxis of stuck places. Educational Theory, 48(4), 487-497.

McLaren, P. (2009). Critical pedagogy: A look at the major concepts. In A. Darder, M. P. Baltodano, \& R. D. Torres (Eds.), The critical pedagogy reader (2nd ed.) (pp. 61-83). New York, NY: Routledge.

Mettler, S. (2014). Degrees of inequality: How the politics of higher education sabotaged the American dream. Basic Books

Monan, J. D. (2009). Value proposition: The worth of a liberal arts education. Boston College Magazine, 24-27.

Mullen, A. L. (2011). Degrees of inequality: Culture, class, and gender in American higher education. JHU Press.

Norris, J., \& Sawyer, R. D. (2012). Toward a dialogic methodology. In Norris, J., Sawyer, R. D., \& Lund, D. (Eds.), Duoethnography: Dialogic methods for social, health, and educational research (pp. 9-39). Walnut Creek, CA: Left Coast Press.

Norris, J., Sawyer, R. D., \& Lund, D. (Eds.). (2012). Duoethnography: Dialogic methods for social, health, and educational research (pp. 9-39). Walnut Creek, CA: Left Coast Press.

Nussbaum, M. (2010). Not for profit: Why democracy needs the humanities. Princeton, NJ: Princeton University Press. 
Palmer, P. J., \& Zajonc, A. (2010). The heart of higher education: A call to renewal: Transforming the academy through collegial conversations. San Francisco, CA: Jossey-Bass.

Pappano, L. (2011, July 22). The master's is the new bachelor's. The New York Times. Retrieved from http://www.nytimes.com/2011/07/24/education/edlife/edl-24masters-t.html?pagewanted=all\&_r=0

Patton, L. D. (2015). Disrupting postsecondary prose: Toward a critical race theory of higher education. Urban Education, 51(3), 315-342. doi:0042085915602542.

Pope, R. L., Reynolds, A. L., \& Mueller, J. A. (2004). Multicultural competence in student affairs. San Francisco: Jossey-Bass.

Rudy, W., \& Brubacher, J. S. (1997). Higher education in transition: A history of American colleges and universities (4th ed.). Piscataway, NJ: Transaction.

Sandeen, A., \& Barr, M. (2006). Critical issues for student affairs: Challenges and opportunities. San Francisco: Jossey-Bass.

Sawyer, R. D. \& Norris, J. (2013). Duoethnography. New York, NY: Oxford University Press.

Seidel, J., \& Hill, L. (2015). Thinking together: A duoethnographic inquiry into the implementation of a field experience curriculum. In Education, 21(2). Retrieved from http://ineducation.ca/ineducation/article/view/219/800

Shor, I. (1992). Empowering education: Critical teaching for social change. Chicago, IL: The University of Chicago Press.

Shor, I. (1996). When students have power: Negotiating authority in a critical pedagogy. Chicago, IL: University of Chicago Press.

Shor, I., \& Freire, P. (1987). What is the dialogical method of teaching? Journal of Education, 169(3), 1131.

Stone, B. B. (2012). Flip your classroom to increase active learning and student engagement. In Proceedings from 28th Annual Conference on Distance Teaching \& Learning, Madison, Wisconsin, USA.

Tassoni, J. P., \& Thelin, W. H. (Eds.). (2000). Blundering for a change: Errors and expectations in critical pedagogy. Portsmouth, NH: Boynton/Cook Publishers.

Thelin, J. (2011). A history of American higher education (2nd ed.). Baltimore: Johns Hopkins University Press.

Tuchman, G. (2009). Wannabe u: Inside the corporate university. Chicago, IL: The University of Chicago Press.

Wilder, C. S. (2014). Ebony and ivy: Race, slavery, and the troubled history of America's universities. Bloomsbury Publishing USA. 


\section{Biographies}

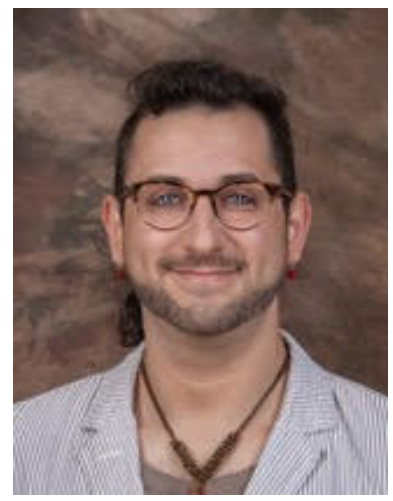

Dr. Z Nicolazzo is an assistant professor in the Adult and Higher Education program and a faculty associate in the Center for the Study of Women, Gender, and Sexuality, both at Northern Illinois University, DeKalb. Z has a B.A. in Philosophy from Roger Williams University (2004), a M.S. in College Student Personnel from Western Illinois University (2006), and a Ph.D. in Student Affairs in Higher Education, with a graduate certificate in Women's, Gender, and Sexuality Studies, from Miami University (2015). Z's research agenda is focused on mapping gender across college contexts, with particular attention to trans* collegians, as well as the intersections of race, gender, sexuality, and disability. Z's book, Trans* in College: Transgender Students' Strategies for Navigating Campus Life and the Institutional Politics of Inclusion, which details an 18-month ethnographic research project alongside trans* collegians in the United States, is forthcoming from Stylus Publishing

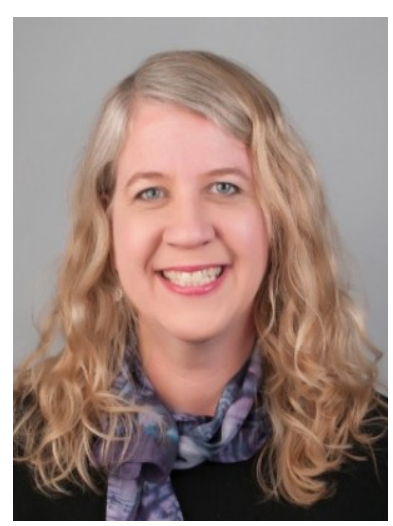

Dr. Susan Marine is an Assistant Professor and Program Director in the Higher Education Graduate Program at Merrimack College. Susan's research interests include feminist education and identity, queer and trans* students and student movements, and sexual violence prevention and intervention on the college campus. A student affairs practitioner for 17 years prior to becoming a faculty member, Susan's teaching and scholarship centers around how institutions can be transformed by liberatory praxis. With Z Nciolazzo, she is currently conducting an ACUHO-I grant funded study critically examining genderinclusive housing practice as an emerging practice, and is the author of the ASHE Higher Education Report, Stonewall's Legacy: Bisexual, Gay, Lesbian and Transgender Students in Higher Education. 